\title{
Impact of Various Tillage and Weed Management Options on Wheat Productivity under New Alluvial Zone
}

\author{
Dhiman Mukherjee* \\ Department of Agronomy, Directorate of Research, Bidhan Chandra \\ Krishi Viswavidyalaya, Kalyani-741235, West Bengal, India \\ *Corresponding author
}

\begin{tabular}{|l|}
\hline Ke y w or d s \\
Economics, \\
tillage, \\
Weed control, \\
Wheat, \\
Yield. \\
\hline Article Info \\
\hline $\begin{array}{l}\text { Accepted: } \\
\text { 30 June } 2017 \\
\text { Available Online: } \\
\text { 10 July } 2017\end{array}$ \\
\hline
\end{tabular}

\section{A B S T R A C T}

Good tillage practice and improved weed management measure enhance wheat productivity to great extent. Uninterrupted nutrient supply during growth period is pivotal to realize full yield potential of a crop. Weeds, being a serious negative factor in crop production, are responsible for marked losses in crop yields. Control of weeds with integrated effort of tillage combined with herbicides may check the loss of these vital inputs to a great extent. A field experiment was conducted during the winter (rabi) season of 2014 and 2015, under the aegis of Bidhan Chandra Krishi Viswavidyalaya at AB block farm, Kalyani. The experiment was carried out in a split plot design with four tillage practices including viz. zero tillage, minimum tillage, conventional tillage and surface seeding in main plot, and six weed management practice viz. weedy check, hoeing (18 DAS) + hand weeding (40 DAS), 2, 4 D Na salt (@750 g a.i/ha), metribuzine (@175 g a.i/ha), hoeing (18 DAS) + 2, 4 D Na salt (@750 g a.i/ha) and hoeing (18 DAS) + metribuzine (@175 g a.i/ha) in subplot, and experiment was replicated thrice. Minimum weed population and dry biomass were recorded in conventional tillage which was at par with minimum tillage with respect to weed population, and significantly lower than surface seeding and zero tillage. Among the various weed management practices, mixed practice of hoeing (18 DAS) + metribuzine (@175 g a.i/ha), and alone application of metribuzine (@175 g a.i/ha) and 2, $4 \mathrm{D} \mathrm{Na}$ salt (@750 g a.i/ha) recorded significantly lower weed population. Hoeing (18 DAS) + hand weeding (40 DAS), registered lowest dry weight of weeds and was at par with the hoeing (18 DAS) + metribuzine (@175 g a.i/ha), and significantly better to other set of treatments. Grain and straw yields in conventional and minimum tillage were at par with each other, and significantly better to other. Increase in grain and straw yield of wheat under conventional and minimum tillage enhance 36.76 and $21.16 \%$ more grain and 48.94 and $33.33 \%$ more straw yield over surface seeding. Maximum grain yields among all subplot treatments, was registered with hoeing (18 DAS) + hand weeding (40 DAS), and was at par with all other treatments except weedy check, 2, 4 D Na salt (@750 g a.i/ha) and hoeing (18 DAS) + 2, 4 D Na salt (@750 g a.i/ha). Highest straw production were recorded in hoeing (18 DAS) + metribuzine (@175 g a.i/ha), which was significantly higher to all other treatment except hoeing (18 DAS) + hand weeding (40 DAS), metribuzine (@175 g a.i/ha) and hoeing (18 DAS) + 2, 4 D Na salt (@750 g a.i/ha). Maximum net profit was recorded with conventional tillage (Rs. $61,544)$ but higher benefit:cost ratio was recorded with minimum tillage options $(2.02)$. Further, more net returns observed with hoeing (18 DAS) + hand weeding (40 DAS) (Rs. 61,568), however more benefit:cost ratio were recorded in metribuzine (@175 g a.i/ha) (2.01). 


\section{Introduction}

Indian agriculture is now at crossroads. We have come a long way. Over the past four decades our strategies, policies and actions were guided by goals of 'self-sufficiency' in food grains production. Indian agriculture has been successful in achieving increased food grains production albeit at a low level of satisfaction. While the mission of increasing food grains production stands somehow achieved, these gains were accompanied by widespread problems of resource degradation, which now pose a serious challenge to the continued ability to meet the demand of an increasing population and lifting our people above the poverty line (Mukherjee, 2015). Wheat (Triticum aestivum L. emend Fiori \& Paol.) is an important crop contributing $40 \%$ in total foodgrain production, and is next only to rice (Oryza sativa L.). Wheat is one of the prehistoric crops and important commodity to our food basket, which provides major energy requirement of the human diet across the world. This is a widely adapted crop, grown to temperate, irrigated to dry and high-rainfall areas and from warm, humid to dry, cold environments. Wheat cultivation mainly depends on improved tillage practice, as most part of India and world also this crop was followed by rice. Due to heavy soil under rice condition, cultivation of wheat mainly depends on good tilth condition. Few of the tillage practices which is now play important role in wheat cultivation are conventional tillage, minimum tillage and zero tillage etc. Most of these tillage operations meant for loosening the soil which inevitably increases its oxygen content leading in turn to the mineralization of the soil organic matter. Zero-till and minimum tillage offered an attractive solution to the problem of late planting. Late planting can be caused by late harvest of the previous rice crop, or by the extensive tillage that farmers must do to convert their physically degraded, puddled rice soil into a suitable seedbed tilth for wheat. Minimum tillage systems are adopted worldwide because of saving in time and economic inputs. However, as tillage is reduced, weed control can become a limiting factor in crop production. Moreover, changes in tillage practices can affect weed population dynamics, including weed seed distribution and abundance in soil seed bank (Christoffoleti et al., 2007). Tillage also reduces number and diversity of weed species, but increase germination of annual weed seeds in the soil seed bank (Mukherjee, 2017). Thus, in no till or minimum tillage system, weed control is largely dependent on herbicide, and appropriate use of herbicides is more important than in traditional tillage system mainly in years with high yield potential. Further, with changing envioronment condition weed problem become diverse type and its taxonomy vary depend on land topography and configuration pattern (Mani and Mukherjee, 2016). Keeping this aspect in mind, present investigation was conducted to the effect of various tillage along with weed management programme on the performance of wheat yield under new alluvial zone.

\section{Materials and Methods}

The field experiment was conducted at District Seed Farm (AB Block), Kalyani under Bidhan Chandra Krishi Viswavidyalaya during winter season of 2014-15 and 2015-16 in upland situation. The farm is situated at approximately $22^{\circ} 56^{\prime} \mathrm{N}$ latitude and $88^{\circ} 32^{\prime}$ E longitude with an average altitude of $9.75 \mathrm{~m}$ above mean sea level (MSL). The soil of the experimental field was loamy in texture and almost neutral in reaction having $\mathrm{pH}$ 7.1, organic carbon $0.42 \%$, available nitrogen 231 $\mathrm{kg}$, available phosphorus 22.2 and available potassium $241 \mathrm{~kg} / \mathrm{ha}$. The experiment was carried out with cultivar DBW 39, in a split plot design with four tillage practices including viz. zero tillage, minimum tillage, 
conventional tillage and surface seeding in main plot, and six weed management practice viz. weedy check, hoeing (18 DAS) + hand weeding (40 DAS), 2, 4 D Na salt (@750 g a.i/ha), metribuzine (@175 g a.i/ha), hoeing (18 DAS ) + 2, 4 D Na salt (@750 g a.i/ha) and hoeing (18 DAS) + metribuzine (@175 g a.i/ha) in subplot, and experiment was replicated thrice. Surface seeding is usually treated as local farmer's practice in the new alluvial zone of west Bengal. The length of each plot was $8 \mathrm{~m}$ (nine rows of wheat). The sowing of crop was done on last week of November, during both the years, using recommended seed rate of $100 \mathrm{~kg} / \mathrm{ha}$. The crop was subjected to recommended package of agronomic and plant protection practices to obtain a healthy crop. Recommended dose of fertilizer apply $\left(150 \mathrm{~kg} \mathrm{~N}, 60 \mathrm{~kg} \mathrm{P}_{2} \mathrm{O}_{5}\right.$ and 40 $\mathrm{kg} \mathrm{K}_{2} \mathrm{O} / \mathrm{ha}$ ) as per need. The crop received full dose of $\mathrm{P}_{2} \mathrm{O}_{5}$ and $\mathrm{K}_{2} \mathrm{O}$ and half dose of nitrogen at basal and remaining nitrogen in two equal splits, i.e. at tillering and at boot stage.

The source of fertilizer was urea, single super phosphate and muriate of potash for $\mathrm{N}, \mathrm{P}$ and $\mathrm{K}$, respectively. In surface seeding, seeds were soaked properly, and planting of soaked seeds treated with fresh cowdung was made in afternoon to save seeds from bird damage. Under zero tillage, stubbles were buried before sowing and seed drills were used to allow planting of wheat seed into fields after rice harvest without ploughing the field. In minimum tillage two disc harrowing were done at $10-15 \mathrm{~cm}$ depth in row zone only after harvest of rice. Conventional tillage included two ploughing with a depth of $40-50 \mathrm{~cm}$, followed by seed bed preparation with harrowing and after this sowing was done. Post emergence application of 2, $4 \mathrm{D} \mathrm{Na}$ salt and metribuzine done 24 days after sowing (DAS). Data on growth, yield components and economic yield were recorded after harvest of crop, whereas leaf area index was recorded at 60 DAS as per normal procedure. Crop and weed sample were analyzed for uptake of nitrogen, phosphorous and potash as per standard laboratory procedure (Jackson, 1973). The experimental data were analyzed statistically by applying the technique of analysis of variance (ANOVA) prescribed for the design to test the significance of overall difference among treatments by the $\mathrm{F}$ test and conclusions were drawn at $5 \%$ probability level. Benefit: cost ratio (B: C) was obtained by dividing the gross income with cost of cultivation. The effect of treatments was evaluated on pooled analysis basis on yield attributes and yields.

\section{Results and Discussion}

The major weeds observed in the experimental plots were: Chenopodium album L., Anagallis arvensis L., Melilotus indica L., Fumaria parviflora L., Convolvulus arvensis L., Vicia sativa L. Asphodelus tenuifolius L., Avena fatua L., Cynodon dactylon L. and Cyperus rotundus $L$.

Minimum weed population and dry biomass were recorded in conventional tillage which was at par with minimum tillage with respect to weed population, and significantly lower than surface seeding and zero tillage (Table 1). Reduced weed population and weed dry biomass under tillage system were due to burying of large number of weed seeds present on the soil surface into deeper layer in the soil which failed to germinate. Among the various weed management practices, mixed practice of hoeing (18 DAS) + metribuzine (@175 g a.i/ha), and alone application of metribuzine (@175 g a.i/ha) and 2,4 D Na salt (@750 g a.i/ha) recorded significantly lower weed population than hoeing and hand weeding, yet weed dry biomass recorded in hand weeded plot was significantly lower than alone chemical weeding operation. Higher weed population in hand weeded plot 
was due to regrowth of surviving weeds and resurgence of weed population with new flushes. Further, table revealed that hoeing (18 DAS) + hand weeding (40 DAS), registered lowest dry weight of weeds and was at par with the hoeing (18 DAS) + metribuzine (@175 g a.i/ha), and significantly better to other set of treatments. Nutrient depletion by weeds revealed that, conventional tillage practice reduce NPK depletion by weeds and recorded significantly lower values than surface seeding and zero tillage but was found to be at par with minimum tillage operation (Table 1). However, the depletion of these nutrients recorded in zero tillage and surface seeding were at par with each other. The reduction of nutrients depletion by weeds in conventional tillage system plots was due to lower dry biomass production. Minimum removal of these nutrients by weeds was registered in hoeing (18 DAS) + hand weeding (40 DAS), plot which was significantly lower than alone herbicidal treatments. Nutrients depletion by weeds recorded in hoeing (18 DAS) + metribuzine (@175 g a.i/ha)was significantly lower compare to all other integrated approach of weed control measures, and was at par with the hoeing (18 DAS) + hand weeding (40 DAS) for all major nutrient, and with hoeing (18 DAS) + 2, 4 D Na salt (@750 $\mathrm{g}$ a.i/ha) for phosphorus uptake pattern. The reduction of nutrients depletion by weeds under hoeing (18 DAS) + hand weeding (40 DAS), was due to less production of weed dry matter. This corroborate with the earlier finding of Singh et al., (2005).

More plant height was observed with conventional tillage, and was at par with minimum tillage option and appreciably better to other set of allotted main plot treatments (Table 1). With various weed management practices, highest plant height was recorded with the hoeing (18 DAS) + metribuzine (@175 g a.i/ha) and was at par with the hoeing (18 DAS) + hand weeding (40 DAS) and hoeing (18 DAS) + 2, 4 D Na salt (@750 g a.i/ha).

LAI failed to produce any significant response with various main plots assignment, however highest LAI recorded with the conventional tillage system and was followed by zero tillage options. Under subplot treatments, more LAI was registered with the hoeing (18 DAS) + metribuzine (@175 g a.i/ha), and was at par with the hoeing (18 DAS) + hand weeding (40 DAS) and hoeing (18 DAS) + 2, 4 D Na salt (@750 g a.i/ha).

Amongst various yield attributing parameters, number of tillers $/ \mathrm{m}^{2}$ was more observed with minimum tillage system and was at par with all other main plots treatments except surface seeding. With various subplot treatments, maximum number of tillers $/ \mathrm{m}^{2}$ was registered with hoeing (18 DAS) + hand weeding (40 DAS), and was statistically at par with the hoeing (18 DAS) + metribuzine (@175 g a.i/ha) and hoeing (18 DAS) + 2, 4 D Na salt (@750 g a.i/ha), and statistically superior to all other allotted treatments. Further, table 1 revealed that, number of earhead $/ \mathrm{m}^{2}$ was maximum with conventional tillage system and significantly better to other main plots treatments. With weed control measures, hoeing (18 DAS) + metribuzine (@175 g a.i/ha) recorded highest number of earhead $/ \mathrm{m}^{2}$ and significantly better to other subplot options.

No. of grains/earhead was maximum found with the conventional tillage and was at par with the minimum tillage practice, and statistically better to other sets to main plots treatments. Weed control measures revealed that, more number of grains/earhead registered with the hoeing (18 DAS) + hand weeding (40 DAS) and was at par with the hoeing (18 DAS) + metribuzine (@175 g a.i/ha). 
Table.1 Effect of tillage and weed management option on weed population, nutrient uptake by weed, growth and maturity parameter of wheat (pooled data of two years)

\begin{tabular}{|c|c|c|c|c|c|c|c|c|c|c|c|c|}
\hline Treatments & $\begin{array}{l}\text { Weed } \\
\text { population }\end{array}$ & $\begin{array}{l}\text { Dry } \\
\text { weight of } \\
\text { weeds } \\
\left(\mathrm{g} / \mathrm{m}^{2}\right)\end{array}$ & \multicolumn{3}{|c|}{$\begin{array}{l}\text { Nutrient uptake by weeds } \\
\text { (kg/ha) }\end{array}$} & $\begin{array}{l}\text { Plant } \\
\text { height } \\
\text { (cm) }\end{array}$ & $\begin{array}{l}\text { LAI } \\
(60 \\
\text { DAS })\end{array}$ & $\begin{array}{l}\text { No. of } \\
\text { tillers/ } \\
\text { m }^{2}\end{array}$ & $\begin{array}{l}\text { No. of } \\
\text { earhea } \\
d / \mathbf{m}^{2}\end{array}$ & $\begin{array}{l}\text { No. of } \\
\text { grains/ } \\
\text { earhead }\end{array}$ & $\begin{array}{l}\text { Days to } \\
50 \% \\
\text { heading }\end{array}$ & $\begin{array}{l}\text { Days to } \\
\text { physiolog } \\
\text { ical } \\
\text { maturity }\end{array}$ \\
\hline \multicolumn{13}{|l|}{ Tillage practices } \\
\hline Zero tillage & $\begin{array}{l}13.63 * * \\
(185.45)^{*}\end{array}$ & $\begin{array}{l}13.02 \\
(169.11)\end{array}$ & 17.89 & 9.68 & 15.69 & 91.23 & 3.61 & 387.16 & 301.34 & 37.13 & 67.62 & 112.66 \\
\hline Minimum tillage & $\begin{array}{l}12.37 \\
(152.66)\end{array}$ & $\begin{array}{l}12.87 \\
(165.26)\end{array}$ & 16.35 & 9.33 & 14.11 & 96.33 & 3.41 & 411.21 & 356.11 & 40.16 & 69.96 & 113.73 \\
\hline Conventional tillage & $\begin{array}{l}11.69 \\
(136.33)\end{array}$ & $\begin{array}{l}10.14 \\
(102.33)\end{array}$ & 15.68 & 8.65 & 13.01 & 97.32 & 3.74 & 405.73 & 382.05 & 41.91 & 71.37 & 112.17 \\
\hline Surface seeding & $\begin{array}{l}14.04 \\
(196.65)\end{array}$ & $\begin{array}{l}13.19 \\
(173.68)\end{array}$ & 18.93 & 10.21 & 16.63 & 89.32 & 3.39 & 311.45 & 286.73 & 37.11 & 72.14 & 111.32 \\
\hline S.Em \pm & 0.28 & 0.33 & 0.46 & 0.31 & 0.37 & 0.66 & 0.74 & 20.36 & 4.32 & 0.65 & 1.09 & 1.21 \\
\hline C.D. $(\mathrm{P}=0.05)$ & 0.89 & 0.98 & 1.41 & 0.95 & 1.23 & 1.93 & NS & 64.52 & 14.56 & 1.86 & 3.21 & NS \\
\hline \multicolumn{13}{|l|}{ Weed management practices } \\
\hline $\begin{array}{l}\text { Hoeing }(18 \text { DAS })+\text { hand } \\
\text { weeding }(40 \text { DAS })\end{array}$ & $\begin{array}{l}13.63 \\
(185.33)\end{array}$ & $\begin{array}{l}8.11 \\
(65.36)\end{array}$ & 10.83 & 6.68 & 9.63 & 95.10 & 3.41 & 413.66 & 319.11 & 43.26 & 69.33 & 112.25 \\
\hline $\begin{array}{l}2,4 \text { D Na salt (@750 g } \\
\text { a.i/ha) }\end{array}$ & $\begin{array}{l}13.37 \\
(178.33)\end{array}$ & $\begin{array}{l}11.90 \\
(141.23)\end{array}$ & 14.21 & 8.48 & 13.25 & 87.33 & 2.90 & 305.12 & 302.11 & 30.21 & 70.45 & 113.45 \\
\hline $\begin{array}{l}\text { Metribuzine ( } \\
@ 175 \text { g a.i/ha) }\end{array}$ & $\begin{array}{l}12.61 \\
(158.66)\end{array}$ & $\begin{array}{l}10.49 \\
(109.61)\end{array}$ & 13.11 & 7.81 & 12.98 & 92.23 & 2.96 & 329.97 & 318.33 & 38.32 & 69.32 & 112.33 \\
\hline $\begin{array}{l}\text { Hoeing }(18 \mathrm{DAS})+2,4 \text { D } \\
\text { Na salt (@ } 750 \mathrm{~g} \mathrm{a.i} / \mathrm{ha})\end{array}$ & $\begin{array}{l}11.21 \\
(125.36)\end{array}$ & $\begin{array}{l}9.47 \\
(89.32)\end{array}$ & 12.14 & 7.18 & 12.01 & 94.22 & 3.12 & 341.32 & 322.11 & 39.11 & 71.23 & 110.89 \\
\hline $\begin{array}{lll}\text { Hoeing }(18 & \text { DAS }) & + \\
\text { metribuzine } & (@ 175 & \mathrm{g} \\
\text { a.i/ha }) & & \end{array}$ & $\begin{array}{l}9.15 \\
(83.25)\end{array}$ & $\begin{array}{l}8.76 \\
(76.32)\end{array}$ & 11.23 & 6.71 & 10.11 & 96.03 & 3.77 & 365.33 & 345.64 & 40.12 & 70.11 & 112.66 \\
\hline S.Em \pm & 0.29 & 0.37 & 0.25 & 0.22 & 0.26 & 0.78 & 0.28 & 26.11 & 5.56 & 1.05 & 0.21 & 0.26 \\
\hline C.D. $(\mathrm{P}=0.05)$ & 0.92 & 1.01 & 0.87 & 0.71 & 0.83 & 2.11 & 0.86 & 77.65 & 16.23 & 3.65 & NS & 0.83 \\
\hline
\end{tabular}

*Figure in parenthesis are original value; **Square root transformed values; NS = Non-significant. 
Table.2 Effect of treatments on yield, nutrient uptake and economics of wheat crop (Pooled data of two years)

\begin{tabular}{|c|c|c|c|c|c|c|c|c|c|}
\hline \multirow[t]{2}{*}{ Treatment } & \multirow[t]{2}{*}{$\begin{array}{l}\text { Grain } \\
\text { Yield } \\
\text { (t/ha) }\end{array}$} & \multirow[t]{2}{*}{$\begin{array}{l}\text { Straw } \\
\text { yield } \\
\text { (t/ha) }\end{array}$} & \multirow[t]{2}{*}{$\begin{array}{l}\text { Harvest } \\
\text { index } \\
(\%)\end{array}$} & \multicolumn{3}{|c|}{$\begin{array}{l}\text { Nutrient uptake by } \\
\text { crops } \\
\text { (kg/ha) }\end{array}$} & \multicolumn{3}{|l|}{ Economics } \\
\hline & & & & $\mathbf{N}$ & $\mathbf{P}$ & $\mathbf{K}$ & $\begin{array}{l}\text { Cost of } \\
\text { cultivation } \\
\text { (Rs./ha) }\end{array}$ & $\begin{array}{l}\text { Net } \\
\text { return } \\
\text { (Rs./ha) }\end{array}$ & $\begin{array}{l}\text { B:C } \\
\text { ratio }\end{array}$ \\
\hline \multicolumn{10}{|l|}{ Tillage practices } \\
\hline Zero tillage & 2.96 & 4.11 & 41.92 & 71.14 & 15.33 & 62.19 & 42,689 & 42,981 & 2.01 \\
\hline Minimum tillage & 3.54 & 5.04 & 41.33 & 84.23 & 16.33 & 64.32 & 59,823 & 60,958 & 2.02 \\
\hline $\begin{array}{l}\text { Conventional } \\
\text { tillage }\end{array}$ & 3.98 & 5.63 & 41.46 & 93.36 & 18.32 & 68.11 & 65,987 & 61,544 & 1.93 \\
\hline Surface seeding & 2.91 & 3.78 & 43.53 & 68.98 & 13.58 & 56.12 & 44,589 & 41,087 & 1.92 \\
\hline S.Em \pm & 0.23 & 0.36 & 0.27 & 1.70 & 0.32 & 1.43 & & & \\
\hline C.D. $(\mathrm{P}=0.05)$ & 0.71 & 1.07 & 0.82 & 5.24 & 1.11 & 4.31 & & & \\
\hline \multicolumn{10}{|c|}{ Weed management practices } \\
\hline Weedy check & 1.98 & 3.12 & 38.81 & 59.11 & 12.45 & 48.36 & 40,981 & 20,156 & 1.49 \\
\hline $\begin{array}{l}\text { Hoeing (18 DAS) } \\
\text { + hand weeding } \\
\text { (40 DAS) }\end{array}$ & 3.96 & 5.68 & 41.07 & 90.12 & 20.15 & 91.32 & 69,899 & 61,568 & 1.88 \\
\hline $\begin{array}{l}\text { 2, } 4 \text { D Na salt } \\
\text { (@750 g a.i/ha) }\end{array}$ & 3.25 & 4.12 & 44.13 & 76.11 & 18.77 & 62.35 & 50,123 & 45,581 & 1.91 \\
\hline $\begin{array}{l}\text { Metribuzine ( } \\
\text { @ } 175 \mathrm{~g} \text { a.i/ha) }\end{array}$ & 3.56 & 5.26 & 40.43 & 81.45 & 19.36 & 74.11 & 51,069 & 51,263 & 2.01 \\
\hline Hoeing (18 DAS) & & & & & & & & & \\
\hline $\begin{array}{l}+2,4 \text { D Na salt } \\
\text { (@750 g a.i } / \mathrm{ha} \text { ) }\end{array}$ & 3.44 & 4.98 & 40.39 & 83.12 & 19.05 & 69.32 & 58,325 & 47,832 & 1.82 \\
\hline $\begin{array}{l}\text { Hoeing (18 DAS) } \\
+ \text { metribuzine } \\
\text { (@ } 175 \mathrm{~g} \mathrm{a.i} / \mathrm{ha})\end{array}$ & 3.88 & 5.98 & 39.78 & 86.52 & 19.98 & 89.21 & 63,125 & 64,321 & 2.02 \\
\hline S.Em \pm & 0.16 & 0.34 & 0.45 & 1.23 & 0.35 & 1.12 & & & \\
\hline C.D. $(\mathrm{P}=0.05)$ & 0.41 & 1.03 & 1.23 & 3.65 & 1.05 & 3.98 & & & \\
\hline
\end{tabular}


Days to $50 \%$ heading revealed that, all tillage option had significant effect on this aspect, among the tillage practice, zero tillage took minimum period (67.62) for $50 \%$ heading followed by minimum tillage options (69.96), whereas the maximum duration (72.41) was observed in case of surface seeding (Table 1). Different soil environment for wheat cultivation might be the reason for difference in crop duration for attaining 50\% heading. However, days to $50 \%$ heading was not affected by various weed control measures.

Further, days to physiological maturity failed to produce any significant response with any tillage practice in main plots. Statistically analysed data on days to physiological maturity (Table 1) revealed that among all the tillage options, earlier maturity was recorded with surface seeding, which took minimum period for attaining physiological maturity followed by conventional tillage practice. With various weed control options, significant response observed, and least time for physiological maturity was recorded with hoeing (18 DAS) + 2, 4 D Na salt (@750 g a.i/ha), and significantly lower to other set of practices in subplots.

Economic yield of wheat significantly influenced by various main and subplots treatments. Grain and straw yields recorded in conventional and minimum tillage were at par with each other, and significantly better to other two set of treatments (Table 2). Further, grain and straw yield of zero tillage and surface seeding were also at par amongst themselves. Moreover, surface seeding gave least economic yield compared to other main plots treatments. Increase in grain and straw yield of wheat under conventional and minimum tillage enhance 36.76 and $21.16 \%$ more grain, and 48.94 and $33.33 \%$ more straw yield over the surface seeding, respectively. The possible reason for higher yield in conventional and minimum tillage was due to more pulverization of soil which favorably enhanced the uptake of nutrients by crop and reduced the state of crop weed completion by lowering the weed population and weed dry biomass. Weed control treatments recorded significantly higher grain and straw yields than weedy check (Table 2). Maximum grain yields among all subplot treatments, was registered with hoeing (18 DAS) + hand weeding (40 DAS), and was at par with all other treatments except weedy check, 2, 4 D Na salt (@750 g a.i/ha) and hoeing (18 DAS) + 2, 4 D Na salt (@750 g a.i/ha). Highest straw production were recorded in hoeing (18 DAS) + metribuzine (@175 g a.i/ha), which was significantly higher to all other treatment except hoeing (18 DAS) + hand weeding (40 DAS), metribuzine (@175 g a.i/ha) and hoeing (18 DAS) + 2, 4 D Na salt (@750 g a.i/ha). Integrated use of hoeing (18 DAS) + metribuzine (@175 g a.i/ha), increase 95.15 and $91.66 \%$ more grain and straw yield respectively, over weedy check. The higher grain and straw yield with the integrated use of hoeing and herbicide application could be ascribed to limited weed intensity (Table 1) which ultimately helped the crop to utilize nutrients, moisture, light and space more efficiently (Mukherjee, 2015; Brar and Walia, 2010). More HI was recorded with farmers practice and significantly better to other set of main plots treatments. Amongst various subplot treatments, more HI was registered with the 2, 4 D Na salt (@750 g a.i/ha) and statistically superior to all other treatments. Significantly more NPK uptake registered with the conventional tillage system and superior to all other main plot treatments except potassium uptake of minimum tillage, where both are at par to each other. Tillage practices reduced the NPK depletion by weeds by $14.32-28.65$, 10.23-18.36, 11.25-21.36\%, and increased NPK uptake by the crop to the extent of 101.25-123.36, 98.36-123.32, 104.31-135.12 $\%$, respectively as compared to surface 
seeding. Higher nutrient uptake in conventional and minimum tillage plots might be due to reduction in the state of crop weed competition by lowering the weed intensity and favorable physical change in soil condition resulted in higher absorption of nutrient by plant. With various weed management practices, highest NPK uptake was registered with the hoeing (18 DAS) + hand weeding (40 DAS), and was at par with the hoeing (18 DAS) + metribuzine (@175 g a.i/ha). Both the treatments were at par with the metribuzine (@175 g a.i/ha) and hoeing (18 DAS) + 2, 4 D (750 g a.i/ha) regarding phosphorus uptake by crop. Least nutrient uptake was recorded with the weedy check plots, and statistically poor to all other management practices. Weed control measures reduced the NPK depletion by weeds to 51.32-69.32, 54.11-67.98 and 31.21$67.33 \%$ and increased NPK uptake by crop to the tune of 112.32-156.11, 123.32-165.36 and 136.13-168.47 \%, respectively, as compared with weedy check (Table 2). Various weed control measures reduced the removal of these nutrients through weeds by reducing the state of crop weed competition and providing more congenial environment for crop growth. Increased uptake of these nutrients by the crop resulted in higher biomass production and hence uptake in grain and straw.

As per economics is concerned, all tillage based practice recorded more net return and benefit: cost ratio compared to usual farmer practices. Maximum net profit was recorded with conventional tillage (Rs. 61,544) but higher benefit:cost ratio was recorded with minimum tillage options (2.02). All the weed control treatments gave considerably higher net profit over weedy check (Table 2). Higher net returns observed with hoeing (18 DAS) + hand weeding (40 DAS) (Rs. 61,568), moreover more benefit: cost ratio were recorded in metribuzine (@175 g a.i/ha) (2.01). Due to higher cost in hand weeding, more net return but lower benefit:cost ratio were found in hoeing (18 DAS) + hand weeding (40 DAS). Susha et al., (2014), reported similar variation in net returns a benefit: cost among treatments due to variation in yield and expenditure incurred by the treatments.

\section{References}

Brar, A.S. and Walia, U.S. 2010. Rice residue position and load in conjunction with weed control treatments interference with growth and development of Phalaris minor Retz. And Wheat (Trititcum aestivum L.). Indian Journal of Weed Science, 42 (3\&4): 163-167.

Christoffoleti, P.J., Pinto, S.J., Carvalho, D., Lopez-Ovejero, R.F., Nicoli, M., Hidalgo, E. and Silva,J.E. 2007. Conservation of natural resources in Brazilian agriculture: Implication on weed biology and management. Crop Protection, 26: 383-389.

Jackson, M.L. 1973. Soil chmical analsysis, pp 183-204. Prentice Hall of India Pvt. Ltd, New Delhi.

Mani, J.K. and Mukherjee, D. 2016. Accuracy of weather forecast for hill zone of West Bengal for better agriculture management practices. Indian Journal of Research, 5(10): 325-328.

Mukherjee, D. 2015. Food security: A worldwide challenge. Research and Review: Journal of Agriculture and Allied Sciences, 4 (1): 3-5.

Mukherjee, D. 2016. Influence of fertility levels on the performance of wheat cultivars under new alluvial zone of West Bengal. Journal of Agroecology and Natural Resource Management, 3(3): 206-208.

Mukherjee, D. 2017. Rising weed problems and their effects on production potential of various crops under changing climate situation of hill. Indian Horticulture 
Journal, 7(1): 85-89.

Singh, R.P., Mukherjee, D and Singh, R.K. 2005. Efficacy of oryzalin on weeds and yield of wheat (Triticum aestivum). Indian Journal of Agronomy, 50 (4): 300-302.
Susha, V.S., Das, T.K., Sharma, A.R. and Nath, C.P. 2014.Carry over effect of weed management practices of maize on weed dynamics and productivity of succeeding zero and conventional till wheat. Indian Journal of Agronomy, 59 (1): 41-47.

\section{How to cite this article:}

Dhiman Mukherjee. 2017. Impact of Various Tillage and Weed Management Options on Wheat Productivity under New Alluvial Zone. Int.J.Curr.Microbiol.App.Sci. 6(7): 4453-4461. doi: https://doi.org/10.20546/ijcmas.2017.607.464 